\title{
The Evaluation Factors Affecting Sleep Quality and Depression Levels in Chronic Hepatitis B and C and Liver Cirrhosis
}

\author{
Elif Yorulmaz' (D, Esra Doğan² (D), Hatice Yorulmaz² (1) \\ 'Departments of Gastroenterology and Internal Medicine, Bağcılar Training and Research Hospital, İstanbul, Turkey \\ ${ }^{2}$ Halic University School of Nursing , İstanbul, Turkey
}

ORCID IDs of the authors: E.Y. 0000-0002-2476-I328; E.D. 0000-0003-2483-6534; H.Y. 0000-0002-0550-9899.

Cite this article as: Yorulmaz E, Doğan E, Yorulmaz H. The Evaluation Factors Affecting Sleep Quality and Depression Levels in Chronic Hepatitis B and C and Liver Cirrhosis. Cyprus J Med Sci 2019; 4(3): 189-94.

\section{BACKGROUND/AIMS}

Physical and mental symptoms, such as sleep disturbances and depression, are common problems in patients with chronic hepatitis $\mathrm{B}$ and $\mathrm{C}(\mathrm{CH}-\mathrm{B}$ and $\mathrm{CH}-\mathrm{C})$ and liver cirrhosis ( $\mathrm{LC}$ ). Poor sleep and depression negatively impact patients' quality of life and cognitive functions. The objective of the present study was to search the affecting factors of sleep quality and depression levels in patients with $\mathrm{CH}-\mathrm{B}, \mathrm{CH}-\mathrm{C}$, and $\mathrm{LC}$.

\section{MATERIAL and METHODS}

We performed a descriptive and cross-sectional study of 135 patients with $\mathrm{CH}-\mathrm{B}$ and $\mathrm{CH}-\mathrm{C}$ and 75 patients with LC in two training hospitals. Data were gathered by application of an introductory form, Pittsburgh Sleep Quality Index, and Beck Depression Scale to 135 patients with $\mathrm{CH}-\mathrm{B}$ and $\mathrm{CH}-\mathrm{C}$ and 75 patients with LC. Percentage, t-test, one way analysis of variance, Tukey test, and Pearson correlation analysis were used for statistical analysis.

\section{RESULTS}

It is found that patients' sleep qualities are meaningfully worse in the hepatitis patient groups that are between 51 and 74 years, female patients who do not have a job and taking antidepressant medicines, patients who have hypertension and taking antihypertension medicines, and patients who have chronic lung diseases and the cirrhosis patient groups that have been treated for a long time than in the other groups. A positive relationship was detected between sleep quality and depression levels in $\mathrm{CH}-\mathrm{B}, \mathrm{CH}-\mathrm{C}$, and LC.

\section{CONCLUSION}

In patients with $\mathrm{CH}-\mathrm{B}, \mathrm{CH}-\mathrm{C}$, and $\mathrm{LC}$, poor sleep quality is strongly related to depression. We suggest that the evaluation and treatment of sleep disturbance to assess patients could improve the quality of life.

Keywords: Cirrhosis, hepatitis B, hepatitis C, dleep quality, depression

\section{INTRODUCTION}

Chronic hepatitis $\mathrm{B}$ and $\mathrm{C}(\mathrm{CH}-\mathrm{B}$ and $\mathrm{CH}-\mathrm{C})$ infection currently is one of the most important health issues worldwide (I). Liver cirrhosis (LC) is a consequence of chronic liver disease most commonly caused by alcoholism, viral hepatitis, autoimmune disorders, or other etiologies. Patients with cirrhosis are exposed to many complications to develop, and thus the average life expectancy decreases significantly. For patients with LC, life becomes meaningless due to symptom-related physical and psychological problems. The incidence rate of negative emotions in patients with chronic hepatitis has been reported to be $38.1 \%-51.1 \%$, among which $47 \%$ of patients have anxiety problems and $68 \%$ of patients have mild-to-moderate depression $(2,3)$.

Regular sleep routine is an important health variable that may affect the quality of life and wellness of the individual. Sleep routine has so many positive effects for human life; however, disturbed sleep affects the individuals negatively and causes problems, such as difficulties in focusing, anxiety, depression, increase in sensitivity to pain, irritability, hallucinations, anorexia, and difficult urination $(4,5)$. Several sleep disturbances have been described in cirrhosis. In chronic diseases, such as $\mathrm{CH}-\mathrm{B}, \mathrm{CH}-\mathrm{C}$, and LC, sleep disturbances, such as difficulty with falling asleep, fragmented nighttime 
sleep, and increased daytime somnolence deterioration in the sleep-wakefulness cycle, may be seen. The patients usually are sleepy during the days and agitated or have difficulties to fall asleep. In some patients, the sleep-wakefulness cycle may even become reversed (6). At the same time, patients with end-stage liver disease have committed suicide because of depression. In our literature search, which we made in our country, we did not find many studies about sleep quality and depression in patients with $\mathrm{CH}-\mathrm{B}, \mathrm{CH}-\mathrm{C}$, and LC. The aim of the present study was to examine (I) what are the sociodemographic factors affecting sleep quality in patients with $\mathrm{CH}-\mathrm{B}, \mathrm{CH}-\mathrm{C}$, and LC?, (2) what are the associated with the disease affecting sleep quality in patients with $\mathrm{CH}-\mathrm{B}, \mathrm{CH}-\mathrm{C}$, and LC?, and (3) what are the sleep quality and depression levels in patients with $\mathrm{CH}-\mathrm{B}, \mathrm{CH}-\mathrm{C}$, and LC?.

\section{MATERIAL and METHODS}

The descriptive and cross-sectional study was conducted on adults diagnosed for at least 6 months, 135 patients with $\mathrm{CH}-\mathrm{B}$ and $\mathrm{CH}-\mathrm{C}$ and 75 patients with LC who voluntarily accepted to participate in the study in two training hospitals with ethical committee confirmation received from the Provincial Directorate of Health of Istanbul. Before the data collection, a written informed consent was also obtained, and the researchers explained the study aims. Data from the patients were obtained upon filling out three forms: introductory information form, Pittsburgh Sleep Quality Index (PSQI), and Beck Depression Scale (BDS). The introductory information form includes sociodemographic variables (age, sex, marital status, educational status, and working status) and disease variables (duration of treatment, used drugs, and additional diseases).

\section{Pittsburgh Sleep Quality Index}

Pittsburgh Sleep Quality Index is a scale employed to determine the sleep quality of the last month and was developed by Buysse et al. (7). The scale consists of 19 questions, and the evaluation of sleep quality is scored as 0 for very good, I for good enough, 2 for bad enough, and 3 for very bad. The global score obtained in the questionnaire ranges between 0 and $2 \mathrm{l}$, and high values indicate bad sleep quality and high sleep disorder level. A global score of 5 indicates a significantly bad sleep quality clinically. The scale was adapted for Turkish patients by Agargun et al. (8).

\section{Beck Depression Scale}

The original form of the scale was prepared by Beck et al. (9). BDS was translated into Turkish, and valid confidence studies have been performed. In the present study, the 1978 version, adapted by Hisli (10), has been used. In the form of BDS, there are four choices for each of 21 symptom categories. Each item may have points between 0 and 3 . The highest score that may be obtained is 63. High total score indicates depression in high level or severity. In our study, Cronbach's alpha coefficient of the scale was read as 0.80 I for patients with hepatitis and 0.804 for patients with cirrhosis.

\section{Statistical Analysis}

All statistical analyses were performed using Statistical Package for the Social Sciences program version I5 (SPSS Inc., Chicago, IL, USA). Descriptive statistics (number, percentage, average score, and standard deviation), t-test, one way variance analysis, Tukey test, and Pearson correlation analysis were used in the statistical analysis of data. Internal consistency was examined through Cronbach's alpha test evaluation. A $p$ value $<0.05$ was considered significant.

\section{RESULTS}

The average age of patients with $\mathrm{CH}-\mathrm{B}$ and $\mathrm{CH}-\mathrm{C}$ included in the study was $45.53 \pm 13.69$ years, and 70 (51.9\%) were females. The average age of patients with LC was $55.64 \pm 11.51$ years, and $29(38.7 \%)$ were females.

It was seen that PSQI scores were higher in the $51-74$ age group in patients with $\mathrm{CH}-\mathrm{B}$ and $\mathrm{CH}-\mathrm{C}$ than in the 19-35 age group $(p<0.05)$. PSQI scores were higher in female patients than in male patients $(p<0.05)$. It was revealed that unemployed patients had higher score than working people $(p \leq 0.01)$. There was no statistically significant difference between marital status and total PSQI score ( $p>0.05)$ (Table I)

TABLE I. Average scores of sociodemographic variables according to PSQI scale in patients with LC

\begin{tabular}{|c|c|c|c|c|c|}
\hline Variable & Variable & $\mathrm{N}$ & $\%$ & Average score $\pm S D$ & Test values \\
\hline \multirow[t]{2}{*}{ Age (year) } & $19-35$ & 38 & 28.1 & $3.81 \pm 2.16$ & $F=3.80$ \\
\hline & $36-50$ & 43 & 31.9 & $5.34 \pm 3.67$ & $p=0.02^{*}$ \\
\hline \multirow[t]{2}{*}{ Sex } & Female & 70 & 51.9 & $5.54 \pm 3.63$ & $t=2.06$ \\
\hline & Male & 65 & 48.1 & $4.41 \pm 2.58$ & $p=0.04^{*}$ \\
\hline Marital status & Single & 25 & 18.5 & $5.88 \pm 3.98$ & $p=0.12$ \\
\hline \multirow[t]{2}{*}{ Working status } & Employed & 40 & 29.6 & $4.0 \pm 2.49$ & $t=2.39$ \\
\hline & Unemployed & 95 & 70.4 & $5.42 \pm 3.39$ & $p=0.01^{* *}$ \\
\hline Educational status & Primary school & 92 & 68.1 & $5.17 \pm 3.05$ & $F=\mid .31$ \\
\hline
\end{tabular}


There was no statistically significant difference between total PSQI score and age groups, gender, marital status, employment status, and education in patients with LC ( $p>0.05)$ (Table 2$)$.

Pittsburgh Sleep Quality Index scores in those who receive antihypertensive treatment were higher than those who do not $(p<0.05)$. Patients who have hypertension $(p \leq 0.01)$ and who have chronic obstructive pulmonary disease (COPD) $(p \leq 0.05)$ had higher PSQI scores than those who do not have. There was no statistically significant difference between total PSQI score and variable of treatment duration in patients with $\mathrm{CH}-\mathrm{B}$ and $\mathrm{CH}-\mathrm{C}$ according to the Tukey test result ( $p>0.05$ ). There was no statistically significant difference between total PSQI score and variables on administration of antiviral drugs $(p>0.05)$ (Table 3 ).

In patients with LC, patients who received treatment since 72396 months had higher scores than those who had treatment duration of 25-60 months according to the Tukey test result $(p<0.05)$. In patients with LC, there was no significant difference between total PSQI scores and variables on antiviral and an- tihypertensive drugs administration status $(p>0.05)$. There was no statistically significant difference between total PSQI scores and condition of having hypertension and COPD in patients with LC ( $p>0.05)$ (Table 4).

We performed Pearson correlation analysis to analyze the relationship between total PSQI score and BDS in patients with $\mathrm{CH}-\mathrm{B}$ and $\mathrm{CH}-\mathrm{C}$, and we determined a weak level significant positive relationship between BDS and total PSQI score $(r=0.439$, $p<0.01)$

With respect to patients with $L C$, we determined a weak level significant positive relationship between BDS and total PSQI score $(r=0.448, p<0.01)$ as a result of Pearson analysis performed to analyze total PSQI score and BDS.

We observed in our study that BDS scores of patients with $\mathrm{CH}-\mathrm{C}$ were higher than those of patients with $\mathrm{CH}-\mathrm{B}$, and patients with cirrhosis had BDS scores higher than those with $\mathrm{CH}-\mathrm{B}$ and $\mathrm{CH}-\mathrm{C}$ $(p \leq 0.01)$ (Table 5).

TABLE 2. Average scores of sociodemographic variables according to PSQI scale in patients with LC

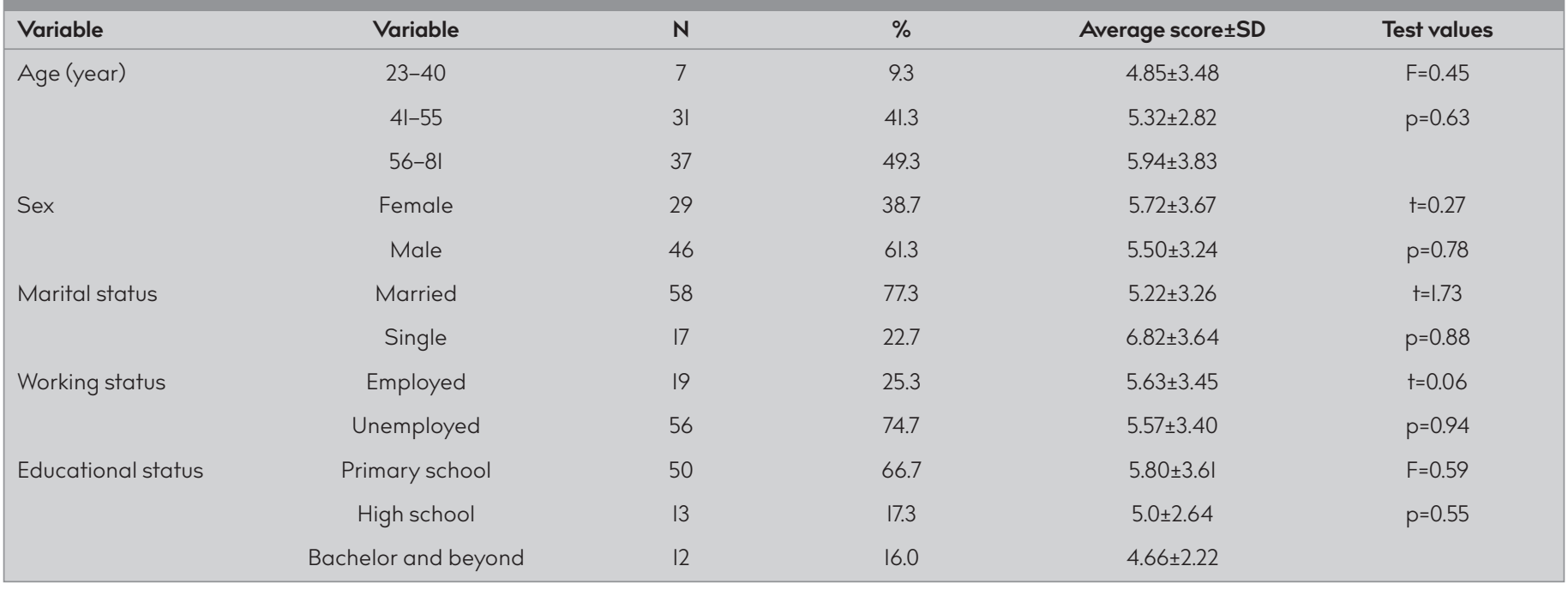

TABLE 3. Average scores of disease variables according to PSQI scale in patients with $\mathrm{CH}-\mathrm{B}$ and $\mathrm{CH}-\mathrm{C}$

\begin{tabular}{|c|c|c|c|c|c|}
\hline Variable & Variable & $\mathbf{N}$ & $\%$ & Average score $\pm S D$ & Test values \\
\hline \multirow{2}{*}{ Treatment duration } & I-24 months & 49 & 36.3 & $4.57 \pm 2.9$ & $p=0.66$ \\
\hline & 61-300 months & 27 & 20.0 & $5.0 \pm 3.08$ & \\
\hline Antiviral drugs & Not used & 77 & 57.0 & $4.79 \pm 3.13$ & $t=0.86$ \\
\hline \multirow[t]{2}{*}{ Antihypertensive drugs } & Not used & III & 82.2 & $4.61 \pm 2.86$ & $t=3.11$ \\
\hline & Used & 24 & 17.8 & $6.79 \pm 4.07$ & $p=0.02^{*}$ \\
\hline \multirow[t]{2}{*}{ Hypertension } & Does not exist & 98 & 72.6 & $4.38 \pm 2.59$ & $t=3.78$ \\
\hline & Exists & 37 & 27.4 & $6.62 \pm 4.05$ & $p=0.01^{* *}$ \\
\hline
\end{tabular}


TABLE 4. Average scores of disease variables according to PSQI scale in patients with $\mathrm{CH}-\mathrm{B}$ and $\mathrm{CH}-\mathrm{C}$

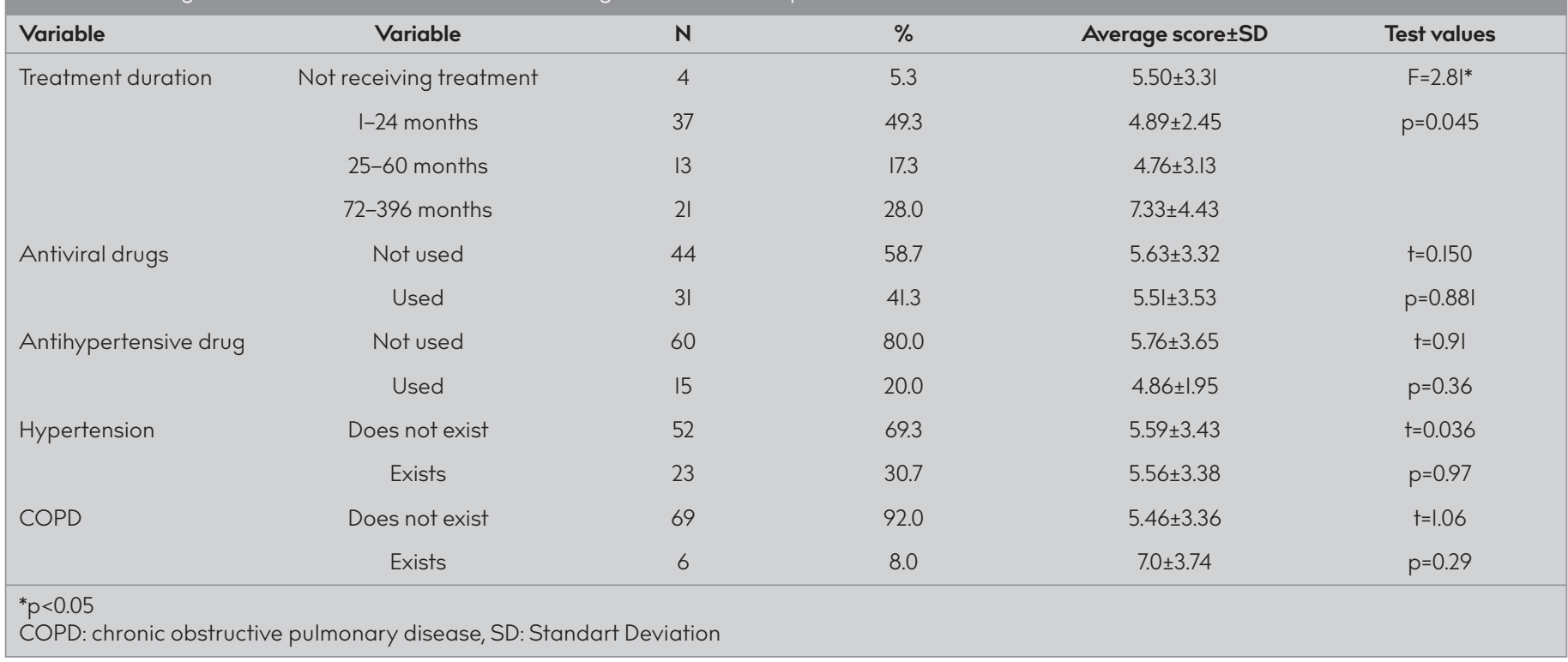

\begin{tabular}{|c|c|c|c|c|}
\hline Variable & Group & $\mathbf{N}$ & Average score $\pm S D$ & Test values \\
\hline \multirow[t]{3}{*}{ BDS } & Hepatitis B & 107 & $8.24 \pm 6.16$ & $t=9.31$ \\
\hline & Hepatitis C & 28 & $11.57 \pm 5.14$ & $\mathrm{p}=\left.0.0\right|^{* *}$ \\
\hline & Cirrhosis & 75 & $12.26 \pm 7.29$ & \\
\hline \multirow[t]{3}{*}{ PSQI } & Hepatitis B & 107 & $4.62 \pm 2.93$ & $t=4.25$ \\
\hline & Hepatitis C & 28 & $6.42 \pm 3.83$ & $p=0.016^{*}$ \\
\hline & Cirrhosis & 75 & $5.58 \pm 3.39$ & \\
\hline
\end{tabular}

${ }^{*} p<0.05,{ }^{* *} p \leq 0.01$

BDS: Beck Depression Scale; PSQI: Pittsburgh Sleep Quality Index

\section{DISCUSSIONS}

Psychiatric disorders are frequent in patients with $\mathrm{CH}-\mathrm{B}$ and $\mathrm{CH}-\mathrm{C}(\mathrm{II})$. While anxiety, distress, and complaints cause a marked stress clinically, they also cause deterioration in social and professional fields or in fields in which functionality is important. Difficulties in focusing his thoughts in a certain subject, undecidedness, suicide thoughts, or attempts can be seen (12).

Liver cirrhosis is a disease that represents the final stage of several chronic liver diseases. Psychological stress and depression seen in LC are related to the severity of the disease (13). In our study, sleep quality was observed to be worse in the 5l-74 age group of patients with $\mathrm{CH}-\mathrm{B}$ and $\mathrm{CH}-\mathrm{C}$ than in the 36-50 and 19-35 age groups of patients with hepatitis and also worse in the $4 \mid-55$ and $56-81$ age groups in patients with LC than in the 23-40 age group. In another study, increasing age of individuals worsened sleep quality. Increasing age was associated with less sleep quality (14).

In the elderly population, sleep quality may deteriorate, depending on physical disorders of which their frequency increases with age, drug usage, sleep disorders, or changes in lifestyle (I5). Furthermore, our study revealed that sleep quality was observed to be worse in female patients with $\mathrm{CH}-\mathrm{B}, \mathrm{CH}-\mathrm{C}$, and $\mathrm{LC}$ than in male patients. A difficult marriage, a second work, or a familial burden absolutely reduces the sleep quantity and deteriorates the circadian rhythm (16).

The fact that the sleep quality of unemployed patients with $\mathrm{CH}-\mathrm{B}$ and $\mathrm{CH}-\mathrm{C}$ was worse than that of employed patients may show us that the reason is a decrease in functional efficiency. Though there was no significant difference in average PSQI scores in patients with hepatitis and cirrhosis from the education status variable, sleep qualities in primary school and high school graduates were worse than those who had a bachelor's or master's degree. An increase in the education level may enable individuals to be less affected from external factors, to develop conscious coping mechanisms, to see in a more realistic way the problems, such as the diseases/symptoms, and thus to have a better sleep quality (17). Sari et al. (18) showed that patients with higher levels of education comply better with the treatment.

In patients with LC, we observe that sleep quality in patients with cirrhosis receiving treatment for 72-396 months long was significantly worse than those receiving treatment for 25-60 months from the treatment duration variable point of view. In LC, complications that appear with the advance of the disease, such as itching, jaundice, hemorrhages, hepatic encephalopathy, and osteoporosis, may cause the deterioration in sleep qualities (19).

With respect to our study, there was no significant difference between patients using antiviral drugs and those who do not among patients with hepatitis and cirrhosis. Notwithstanding, it was determined that sleep qualities in patients with hepatitis using antiviral drugs were worse than those who did not use. It was concluded in the study performed by Carlson et al. (20) in which different antiviral drugs were administered to hepatitis $C$ that antiviral drugs caused effects, such as myalgia and anorexia, and thus lead to sleep disorders.

In our study, we observed that patients with $\mathrm{CH}-\mathrm{B}$ and $\mathrm{CH}-\mathrm{C}$ who have hypertension as an additional disease had worse 
sleep qualities than those who do not have hypertension. In addition to these factors, the presence of an additional disease in our patients caused their sleeping mode to be affected (2I). Sleep qualities of our patients using antihypertensive drugs were concluded to be worse than those who did not use antihypertensive drugs. Yilmaz et al. (22) showed that beta-blockers, such as metoprolol, which is used in the treatment of hypertension, deteriorate the sleep quality.

We observed in our study that sleep quality in patients with hepatitis and cirrhosis who also had COPD was worse than those who had no COPD. It was shown in the study by Cinar and Olgun (23) that signs, such as cough and phlegm in patients with COPD, caused sleep disorders in patients.

Our study revealed that patients with hepatitis $C$ had higher BDS scores than those with hepatitis B, and patients with cirrhosis had higher than those with hepatitis B and C. PSQI scores were higher in patients with hepatitis $C$ than in those with cirrhosis and higher in patients with cirrhosis than in those with hepatitis B. It was observed that $48.6 \%$ of 107 patients infected with $\mathrm{CH}-\mathrm{B}$ and $\mathrm{CH}-\mathrm{C}$ had at least one psychiatric disorder, and that $15 \%$ of the patients met the major depression criteria. Moreover, in the same study, there was no statistically significant difference in patients with $\mathrm{CH}-\mathrm{B}$ and $\mathrm{CH}-\mathrm{C}$ from the psychiatric diagnosis rates point of view; however, scores of quality of life in both groups were found to be significantly lower than those in the control group. It was observed that psychiatric comorbidity, particularly depression, was the most important variable that reduced the quality of life (24). In the study performed by Ozkan et al. (II), both the $\mathrm{CH}-\mathrm{B}$ and $\mathrm{CH}-\mathrm{C}$ groups had patients with mild depression.

Mechanisms lying under the fact that chronic hepatitis B virus (HBV) was less associated with psychiatric symptoms are still under examination. Some studies indicate the differences related to the viruses. It was suggested that hepatitis $C$ virus has direct neurotoxic effect in the brain, the same as human immunodeficiency virus, and therefore, its neuropsychiatric effects are greater. However, a similar observation could not be done in patients with HBV $(25,26)$. Our study further revealed that sleep quality was bad in patients with cirrhosis. Montagnese et al. (27) reported that sleep wave anomalies are recorded in patients with cirrhosis.

The limitations of our study include a small size patient group.

In conclusion, we observed that our patients with cirrhosis had mild depression according to BDS evaluation. The fact that the signs of the disease appear more severe in patients with LC and hepatitis $C$ in our study than in patients with hepatitis $B$ and reasons, such as poor prognosis of disease, may increase the tendency to depression. We found that patients' sleep qualities are meaningfully worse in elderly patients with hepatitis, female patients who do not have a job and taking antidepressant medicines, patients who have hypertension and taking antihypertension medicines, patients who have chronic lung diseases, and cirrhosis patient groups that have been treated for a long time than in other groups. In addition, there was a positive relationship between sleep quality and depression levels in $\mathrm{CH}-\mathrm{B}, \mathrm{CH}-\mathrm{C}$, and LC. $\mathrm{CH}-\mathrm{B}, \mathrm{CH}-\mathrm{C}$, and $\mathrm{LC}$ are important health problems, which can affect the individual and the people around him/her bodily, socially, and psychologically. Education and psychiatric approach are key factors in the treatment and follow-up of these diseases.

Ethics Committee Approval: Ethics committee approval was received for this study from Istanbul Provincial Health Directorat (Approval Date: 17.02.2015, Approval Number: 156).

Informed Consent: Informed consent was obtained from the patients who participated in this study.

Peer-review: Externally peer-reviewed.

Author contributions: Concept - H.Y; Design - E.Y.; Supervision - E.Y; Resource - E.Y.; Materials E.D.; Data Collection and/or Processing - E.D.; Analysis and/or Interpretation - H.Y.; Literature Search E.D.; Writing E.D.; Critical Reviews - E.Y.

Conflict of Interest: The authors have no conflicts of interest to declare.

Financial Disclosure: The authors declared that this study has received no financial support.

\section{REFERENCES}

I. Dogan O, Ertekin S, Dogan S. Sleep quality inhospitalized patients. J Nurs 2005; 14: 107-13. [CrossRef]

2. Sherlock S, Dooley J., editors. Diseases of the Liver and Biliary System. Ilth Edition. Blackwell Science; Oxford, UK: Malden, MA; 2002. p. 65

3. Schiff ER, Sorrell MF, Maddrey, EC., editors. Schiff's Diseases of the Liver. 9th Edition. Lippincott, Williams d Wilkins: Philadelphia; 2003. p. 3 .

4. Benca RM, Obermeyer WH, Thisted RA, Gillin JC. Sleep and psychiatric disorders; a meta analysis. Arch Gen Psychiatry 1992; 49: 65I-68. [CrossRef]

5. Doi Y, Minowa M, Uchiyama M, Okawa M, Kim K, Shibui $K$, et al. Psychometric assessment of subjective sleep quality using the Japanese version of the Pittsburgh Sleep Quality Index (PSQI-J) in psychiatric disordered and control subjects. Psychiatry Res 2000; 97: 165-72 [CrossRef]

6. Reddy KR, Wright TL, Pockros PJ, Shiffman M, Everson G, Reindollar $R$, et al. Efficacy and safety of pegylated (40-kd) interferon alpha-2a compared with interferon alpha-2a in noncirrhotic patients with chronic hepatitis C. Hepatology 200I; 33: 433-8. [CrossRef]

7. Buysse DJ, Reynolds CF, Monk TH, Berman SR, Kupfer DJ. The Pittsburgh sleep quality index: A new instrument for psychiatric practice and research. Psychiatry Res 1989; 28: 193-213. [CrossRef]

8. Agargun $Y M$, Kara $H$, Anlar $O$. The Validity and Reliability of the Pittsburgh Sleep Quality Index. Turk J Psych 1996; 7: 107-II.

9. Beck AT. An inventory for measuring depression. Arch Gen Psychiatry 1961; 4: 561-7I. [CrossRef]

10. Hisli N. The Validation of Beck Depression Inventory for University Students. Turkish J of Psychol 1989; 7: 3-I3.

II. Ozkan M, Corapçioglu A, Balcioglu I, Ertekin E, Khan S, Ozdemir S, et al. Psychiatric morbidity and its effect on the quality of life of patients with chronic hepatitis B and hepatitis C. Int J Psychiatry Med 2006; 36: 283-97. [CrossRef]

12. Balcioglu I, Ozdemir S. Psychiatric Findings in patients wth chronic hepatitis Tabak F, Balık I, Tekeli E (editors). Ankara, Viral Hepatitis Prevention Society; 2005. p.76-82.

13. Abbas G, Jorgensen RA, Lindor KD. Fatigue in primary biliary cirrhosis. Nat Rev Gastroenterol Hepatol 2010; 7: 313-9. [CrossRef]

14. Unsal A, Demir G. Evalution of sleep quality and fatigue in hospitalized patients. International Journal of Caring Sciences 2012; 5: 311319 
15. Kamel NS, Gammack JK. Insomnia in the elderly: Cause, approach, and treatment. Am J Med 2006; 119: 463-9. [CrossRef]

16. Lindberg E, Carter N, Gislason T, Janson C. Role of snoring and daytime sleepiness in occupational accidents. Am J Respir Crit Care Med 200I; 164: 203I-5. [CrossRef]

17. Patel NP, Grandner MA, Xie D, Branas CC, Gooneratne N. Sleep disparity in the population: poor sleep quality is strongly associated with poverty and ethnicity. BMC Public Health 2010; 10: 475. [CrossRef]

18. Sarı F, Sarıkaya M, Eren M, Gunes AJ,Korkmaz A, Cetinkaya R. The Effect of Demographical and Social Parameters on Patient Survey in Peritoneal Dialysis Patients. Turk J Nephrol 2010; 19: 121-3. [CrossRef]

19. Sherlock S, Dooley J. Hepatic cirrhosis. Sherlock S, Dooley J (editors): Disease of liver and biliary system. Oxford: Blackwell scientific; 2002. p. 365-78. [CrossRef]

20. Carlson MD, Hilsabeck RC, Barakat F, Perry W. Role of Sleep Disturbance in Chronic Hepatitis C Infection. Curr Hepat Rep 20I0; 9: 25-9. [CrossRef]

21. Shelton L. Disease management accreditation: quality improvement in a new health care Environment. Dis Manag 2003; 6: 53-6. [CrossRef]
22. Yilmaz MB, Erdem A, Yalta K, Turgut OO, Yilmaz A, Tandogan I. Impact of beta-blockers on sleep in patients with mild hypertension: a randomized trial between nebivolol and metoprolol. Adv Ther 2008; 25: 87I-83. [CrossRef]

23. Cinar S, Olgun N. Determining of Fatigue and Sleep Disturbance in Patients with Chronic Obstructive Pulmonary Disease. Turkiye Klinikleri J Nurs Sci 20I0; 2: 24-31

24. Ozdemir S, Yalug I, Mert A, Aker T. Chronic hepatitis from a psychiatric point of view. Anatolian J Psych 2008; 9: 253-60

25. Radkowski M, Gallegos-Orozco JF, Jablonska J, Colby TV, Walewska-Zielecka B, Kubicka J, et al. Persistence of hepatitis C virus in patients successfully treated for chronic hepatitis C. Hepatology 2000; 41: 106-14. [CrossRef]

26. Forton DM, Taylor-Robinson SD, Thomas HC. Cerebral dysfunction in chronic hepatitis C infection. J Viral Hepat 2003; 10: 81-6. [CrossRef]

27. Montagnese S, Middleton B, Skene DJ, Morgan MY. Night-time sleep disturbance does not correlate with neuropsychiatric impairment in patients with cirrhosis. Liver Int 2009; 29: 1372-82. [CrossRef] 